\title{
Studerendes forventninger til vejledning på skriftlige opgaver
}

Henriette Lyngstrøm er lektor og studieleder på Forhistorisk Arkcelogi, Københavns Universitet.

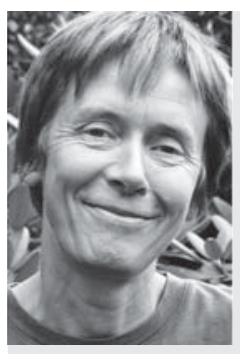

Henriette Lyngstrøm er mag.art., ph.d. i forhistorisk arkæologi og lektor på Københavns Universitet. Hun har siden 1995 undervist i arkæologi på Universitetet i Oslo og på Københavns Universitet og var 2003-2007 fagets studieleder i København.

Denne artikel handler om universitetsstuderendes forventninger til vejledning på skriftlige opgaver. Undersøgelsen er foretaget på kandidat- og magisterkonferensuddannelsen $i$ faget Forhistorisk Arkceologi, Kobenhavns Universitet og dens udgangspunkt var at undersøge de forventninger, studerende har til en kommende vejledning.

Ideen var at udvikle den vejledning, der tilbydes i forbindelse med uddannelses tre typer skriftlige opgaver. Det kunne selvfolgelig ske alene ud fra, hvordan vejledningen praktiseres og evalueres, men på faget mente vi, at vores grundlag blev mere alsidigt, hvis de studerende gav udtryk for deres forventninger - uafhengigt af den eksisterende vejledning.

\section{Baggrunden for undersøgelsen}

I efteråret 1999 foretog det Humanistiske Fakultets Studiekontor på Københavns Universitet en studentertilfredshedsundersøgelse på faget forhistorisk arkæologi, der med fem faste undervisere og 225 studerende er et af institutionens mindre fag.

I undersøgelsen blev fagets vejledningspraksis udsat for massiv kritik. Især var det fraværet af vejledning på overbygningsuddannelsernes (kandidat- og magisterkonferensuddannelsernes) skriftlige arbejder, der blev kritiseret. Således svarede 50 ud af 69 studerende, at de havde modtaget "ingen" eller "utilstrækkelig" vejledning i forbindelse med udarbejdelsen af deres skriftlige hjemmeopgaver. "Jeg har aldrig andet end selv valgt emne evt. fået det godkendt og derefter afleveret det«. Og 24 studerende vurderede de emner, lærergruppen kunne give vejledning indenfor, som "utilfredsstillende" eller "meget utilfredsstillende«. Det var såvel vejledningens kvantitet, „Da der ikke er undervisning i opgaveskrivning, er det rimeligt at forlange mere vejledning", som kvalitet, "Jeg kunne have brugt mine vejledere mere, men udbyttet var for ringe «, der blev kritiseret. Men også vejledernes attituder var kritisable: „Lærerne bør give sig bedre tid til vejledning og virke mere interesserede" og "Man bliver ofte mødt med irritation, hvis man ønsker vejledning". (Citaterne er hentet fra Studentertilfredshedsundersøgelsen 1999,25f).

Som følge af undersøgelsen kom fagets vejledningspraksis i fokus, og der blev gjort et konstruktivt arbejde for at rette op på de kritisable forhold. Indsatsen var dog på ingen måde systematiseret, og blev overvejende drevet af det, man kunne karakterisere som den enkeltes gode vilje til at ville samtalen. For på faget var der enighed om, at vejledningen var vigtig - især på overbygningsuddannelsernes studieelementer, hvortil der ikke var knyttet skemalagt undervisning.

Men den øgede opmærksomhed på faglig dialog kom hurtigt til at resultere $\mathrm{i}$, at vejledning blev praktiseret og forventet $i$ et stadigt stigende omfang i tilknytning til alle de skriftlige opgaver på fagets overbygning - skønt fagets studieordning udelukkende nævnte vejledning i forbindelse udarbejdelsen af specialet. På den måde blev det almindeligt, at enkelte undervisere anvendte 70 timer pr. semester alene på vejledning i tilknytning til tema- og projektopgaver.

Det blev derfor nødvendigt at etablere en fast vejledningspolitik med formelle retningslinier for omfang og indhold. Og undersøgelsen af de studerendes forventninger til vejledning i forbindelse med skriftlige opgaver skulle bruges til at definere og sikre kvaliteten af vejledningen. Det kunne selvfølgelig være gjort på traditionel vis, med udgangspunkt i praksis og evalueringer, men ved at tage udgangspunkt i de studerendes forventninger til, og måske drømme om, et ideelt vejledningsforløb, har vi kunnet opstille bredere rammer. 


\section{Undersøgelserne}

Der blev foretaget to spørgeskemaundersøgelser af de studerendes forventninger til vejledning. Det skete med fire års mellemrum, nemlig i november 2002 og igen $i$ august 2006. Spørgsmålene i de to undersøgelser var enslydende og omfattede forventningerne til vejledning på tre typer skriftlige opgaver: kulturhistoriske temaopgaver, projektrefleksioner og specialer.

Spørgeskemaerne indeholdt 12 punkter. Et afklarende spørgsmål vedrørende den studerendes studieprogression efterfulgt af 11 spørgsmål med en direkte relation til forventningerne. For at nå et så bredt udsnit af fagets studerende som muligt, blev spørgeskemaerne fremlagt på læsesale, hængt op på opslagstavler og rundsendt elektronisk. De studerende blev opfordret til at udfylde et skema for hvert af de vejledningsforløb, de havde forventninger til og blandt de omkring 100 studerende, der er indskrevet på kandidat- eller magisterkonferensuddannelsen i forhistorisk arkæologi, blev der indsamlet forventninger til henholdsvis 52 (2002) og 57 (2006) vejledningsforløb. Forventningerne fordelte sig nogenlunde jævnt mellem uddannelsernes første, andet og tredje studieår og en stor del af besvarelserne kom fra studerende, der opholdt sig på udgravninger rundt omkring i Danmark. De befandt sig altså ikke rent fysisk på universitetet $\mathrm{i}$ den periode, undersøgelsen blev foretaget. Der er derfor god grund til at formode, at besvarelserne er repræsentative for studentergruppen. Ikke alle studerende besvarede alle undersøgelsens spørgsmål.

\section{Forventninger til vejledningens form}

Hovedparten af fagets studerende begynder arbejdet på overbygningsniveau med en af de to temaopgaver. Kravene til begge disse skriftlige opgaver er enslydende. Og de er enslydende, hvad enten den studerende har valgt at studere under kandidat- eller under magisterkonferensordningen.

Temaopgaven er en fri hjemmeopgave på 25-30 sider, udgør 15 ECTS og bedømmes ved intern censur efter 13-skalaen.

Det er her værd at bemærke, at hovedparten af de studerende forventer 2-3 vejledningsmøder på $30 \mathrm{mi}-$ nutter og at ingen $(\bmod 7,4 \%$ i 2002$)$ forventer, at vejledningsmøder i tilknytning til temaopgaverne skal vare længere end $1 / 2$ time. Kun $31,7 \%$ af de studerende har en forventning om, at vejledningen tager sigte mod et bestemt karakterniveau på den færdige opgave. En øget andel af de adspurgte, $68,9 \%(\bmod 52 \%$ i 2002$)$, har ingen forventninger om, at vejledningen skal sigte på en bestemt karakter. Halvdelen af de studerende forventer, at vejleder har læst et par sider inden opgaven afleveres.

\begin{tabular}{|l|c|c|}
\hline $\begin{array}{l}\text { Temaopgaven, den akademiske opgave } \\
\text { på } 25-30 \text { sider }\end{array}$ & 2002 & 2006 \\
\hline Forventninger til antal møder & & \\
\hline I-2 møder & $15,2 \%$ & $25,0 \%$ \\
\hline $2-3$ møder & $22,8 \%$ & $68,7 \%$ \\
\hline $4-5$ møder & $49,4 \%$ & $6,3 \%$ \\
\hline Mere end 5 møder & $11,4 \%$ & $0,0 \%$ \\
\hline Forventninger til mødelængde & & \\
\hline I5 min. & $37,0 \%$ & $25,0 \%$ \\
\hline 30 min. & $48,1 \%$ & $75,0 \%$ \\
\hline Længere end 30 min. & $7,4 \%$ & $0,0 \%$ \\
\hline Forventninger til karakterniveau & & \\
\hline Topkarakter & $28,0 \%$ & $21,2 \%$ \\
\hline Middelkarakter & $20,0 \%$ & $10,5 \%$ \\
\hline Ingen karakter & $52,0 \%$ & $68,9 \%$ \\
\hline Forventninger til gennemlæsning & & \\
\hline Alle 25-30 sider & $4,0 \%$ & $6,25 \%$ \\
\hline Omkring I5 sider & $24,0 \%$ & $25,0 \%$ \\
\hline Et par sider & $60,0 \%$ & $50,0 \%$ \\
\hline Ingen sider & $12,0 \%$ & $18,8 \%$ \\
\hline & & \\
\hline & & \\
\hline & & \\
\hline & & \\
\hline
\end{tabular}

Figur I. Forventninger til vejledning i forbindelse med skriftlige opgaver på 25-30 sider

Overbygningens to projekter udgør 15 ECTS hver. Men her er der forskel på, om den studerende har valgt kandidat- eller magisterkonferensuddannelsen. På kandidatuddannelsen er fordringerne til projektopgaverne enslydende. Begge projekter skal afleveres som bilag til en 5-10 siders reflekterende, skriftlig fremstilling, hvori der gøres rede for den valgte fremgangsmåde i projektet. Projektopgaverne bedømmes ved ekstern censur med bestået/ikke bestået. På magisterkonferensuddannelsen er de to projekter specificeret som henholdsvis formidling og feltarbejde/udgravning. Også disse afleveres som bilag til en reflekterende, skriftlig fremstilling på 5-10 sider, hvori der gøres rede for den valgte fremgangsmåde i projektet. Begge projektrefleksioner bedømmes ved ekstern censur efter 13-skalaen.

I forbindelse med forventningerne til vejledningen på refleksionerne er det værd at bemærke, at $63 \%$ af de studerende forventer 2-3 vejledningsmøder, mens kun $12,5 \%(\bmod 27,3 \%$ i 2002$)$ har en forventning om 4-5 møder. Og at de fleste studerende forventer møder, der varer 30 minutter. Det er $40 \%$, der har en forventning om, at vejledningen tager sigte mod et bestemt karakterniveau. Af dem har alle (mod kun 30 \% i 2002) en forventning om, at den tager sigte på en topkarakter. $60 \%$ af de studerende har ingen forventninger om, at vejledningen på projekter tager sigte 
på en bestemt karakter, hvilket kan skyldes, at hovedparten af de studerende, der besvarede spørgeskemaet er indskrevet på kandidatuddannelsen, hvor refleksionerne bliver bedømt med bestået/ikke bestået. Også her havde halvdelen af de studerende en forventning om, at vejlederen læser et par sider igennem inden aflevering.

\begin{tabular}{|l|r|r|}
\hline $\begin{array}{l}\text { Projektet, } \\
\text { en refleksion på 5- I0 sider }\end{array}$ & 2002 & 2006 \\
\hline Forventninger til antal møder & & \\
\hline I-2 møder & $9,1 \%$ & $13,0 \%$ \\
\hline $2-3$ møder & $63,7 \%$ & $62,5 \%$ \\
\hline $4-5$ møder & $27,3 \%$ & $12,5 \%$ \\
\hline Mere end 5 møder & $0 \%$ & $0 \%$ \\
\hline Forventninger til mødelængde & & \\
\hline I5 min. & $18,2 \%$ & $37,5 \%$ \\
\hline 30 min. & $72,8 \%$ & $62,2 \%$ \\
\hline Længere end 30 min. & $9,1 \%$ & $0 \%$ \\
\hline Forventninger til karakterniveau & & \\
\hline Topkarakter & $30,0 \%$ & $40,0 \%$ \\
\hline Middelkarakter & $30,0 \%$ & $0 \%$ \\
\hline Ingen karakter & $40,0 \%$ & $60,0 \%$ \\
\hline Forventninger til gennemlæsning & & \\
\hline Alle 25-30 sider & $37,5 \%$ & $50,0 \%$ \\
\hline Omkring I5 sider & $33,2 \%$ & $12,5 \%$ \\
\hline Et par sider & $12,5 \%$ \\
\hline Ingen sider & $25,0 \%$ \\
\hline & & \\
\hline & & 0 \\
\hline
\end{tabular}

Figur 2. Forventninger til vejledning i forbindelse med skriftlige projektrefleksioner på 5-10 sider

Den afsluttende opgave på begge studieordninger er specialet, der svarer til henholdsvis 30 eller 60 ECTS. Specialet på kandidatuddannelsen er på højst 60 sider, efterfølges af en forelæsning på 30 minutter og bedømmes ved ekstern censur efter 13-skalaen. På magisterkonferensuddannelsen er specialet på højst 120 sider, efterfølges af en forelæsning på 45 minutter og bedømmes ved ekstern censur med bestået/ikke bestået.

Blandt de specialestuderende er det bemærkelsesværdigt, at knap halvdelen forventer 5-6 møder og $29,5 \%$ mere end syv møder. De fleste, 70,8 \%, forventer møder, der varer 30 minutter, mens kun 5,7 \% forventer 60 minutter lange vejledningsmøder. Det er halvdelen af de studerende, der har en forventning om, at specialevejledningen tager sigte mod et bestemt karakterniveau. Deraf mener de fleste, at den skal tage sigte på en topkarakter. Men knap $20 \%$ har - modsat tallene for 2002 - forventninger om en middelkarakter. Halvdelen af de studerende har ingen forventninger om, at vejledningen skal sigte på en bestemt karakter. Disse tal kan tolkes som en voksende realitetssans hos de studerende, men den gunstige situation på arbejdsmarkedet må heller ikke underkendes i denne sammenhæng. Igen er det hovedparten af de studerende, der forventer halvdelen af teksten gennemlæst inden aflevering.

\begin{tabular}{|l|r|r|}
\hline $\begin{array}{l}\text { Specialet, } \\
60 \text { eller I20 sider }\end{array}$ & 2002 & 2006 \\
\hline Forventninger til antal møder & & \\
\hline I-2 møder & $0 \%$ & $0 \%$ \\
\hline $2-3$ møder & $0 \%$ & $5,9 \%$ \\
\hline $4-5$ møder & $0 \%$ & $17,6 \%$ \\
\hline $5-6$ møder & $37,5 \%$ & $47,2 \%$ \\
\hline Mere end 7 møder & $62,5 \%$ & $29,5 \%$ \\
\hline Forventninger til mødelængde & & \\
\hline I5 min. & $12,5 \%$ & $23,5 \%$ \\
\hline 30 min. & $50,0 \%$ & $70,8 \%$ \\
\hline Længere end 30 min. & $5,9 \%$ & $5,7 \%$ \\
\hline Forventninger til karakterniveau & & \\
\hline Topkarakter & $57,1 \%$ & $31,3 \%$ \\
\hline Middelkarakter & $0 \%$ & $18,8 \%$ \\
\hline Ingen karakter & $42,9 \%$ & $50,0 \%$ \\
\hline Forventninger til gennemlæsning & & \\
\hline Alle 60 eller I20 sider & $25,0 \%$ & $12,5 \%$ \\
\hline Omkring halvdelen & $25,0 \%$ & $75,0 \%$ \\
\hline Et par sider & $12,5 \%$ & $12,5 \%$ \\
\hline Ingen sider & $0 \%$ \\
\hline I $\%$ \% Forv $\%$ \\
\hline
\end{tabular}

Figur 3. Forventninger til vejledning i forbindelser med specialer på 60 eller 120 sider

\section{Forventninger til vejledningens indhold}

På alle tre typer skriftlige arbejder gælder det, at næsten alle studerende forventer, at vejledningsmøderne vil blive brugt til diskussion af problemformulering og af opgavens struktur, mens $82 \%$ forventer henvisninger til litteratur og vejledning i specifikke, faglige problemer. 69,2\% venter at fă kontakt til relevante fagmiljøer og -personer gennem vejledningen, og 48,7 \% venter vejledning $\mathrm{i}$ arbejdsprocessen. En tredjedel af de studerende forventer desuden vejledning $i$ formalia $i$ forbindelse med deres skriftlige opgave.

Med hensyn til vejlederen selv prioriterede de studerende helt overraskende i begge undersøgelser og på næsten alle studieelementer forventningen om, at vejleder var forberedt til møderne og overholdt de indgåede aftaler højere end forventningen om, at vejleder havde en specifik, faglig indsigt. Kun i ét tilfælde, ved 
forventningerne til specialevejledningerne i 2002, svarede de studerende, at de prioriterede en vejleder med specifik faglig indsigt højere end forventningerne til, at vejleder holdt de indgåede aftaler. Kun få studerende forventede, at vejlederen skulle rette i deres tekster og næsten igen forventede, at vejlederen ville være enig med dem.

Det var interessant, at der i 2006 var en øget forventning til, at vejledningen ville fă betydning for, om arbejdet kunne afsluttes til fastsat tid. Og til om den studerende blev tilfreds med sin skriftlige opgave. Således venter $57,5 \%$ af de studerende $(\bmod 43,4 \%$ i 2002), at vejledningen vil have "en del betydning«, og $5 \%(\bmod 0 \%$ i 2002$)$ at den vil have "altafgørende antallet af prioriteringer. Højest prioriterede element har laveste værdi.

\section{Fremtidig vejledningspolitik}

Hensigten med undersøgelserne af de studerendes forventning til vejledning på skriftlige opgaver var at etablere en vejledningspolitik, der opstillede klare men fleksible rammer for vejledning. Rammer, der kunne fungere som et udgangspunkt for udvikling af praksis. Efter undersøgelserne af de studerendes forventninger kan rammerne skitseres således:

1. Der tilbydes vejledning på alle overbygningsuddannelsernes skriftlige opgaver.

2. På tema- og projektopgaver tilbydes 2-3 møder á 30 minutter. Vejledningen tager ikke sigte på et bestemt karakterniveau, men drejer sig primært om opgavens problemformulering, litteratursøgning, specifikke faglige problemer, arbejdsprocessen og henvisninger til relevante fagmiljøer. Vejlederen er forberedt til møderne, overholder de aftaler, der indgås, og læser gerne et par sider færdig tekst igennem, inden opgaven afleveres.

3. På specialer tilbydes 5-7 møder á 30 minutter. Vejledningen kan tage sigte på et bestemt karak-
Og $62,5 \%(\bmod 56,7 \%$ i 2002$)$ venter, at vejledningen vil have "en del betydning « og 7,5\% (mod $0 \%$ i 2002) at den vil have "altafgørende betydning « for, om den studerende blev tilfreds med resultatet.

Modsat er der en svækket forventning til, om vejledningen har betydning for den karakter, den studerende opnår på sin skriftlige opgave. $55 \%(\bmod 67,4 \%$ i 2002) af de studerende forventer, at vejledningen får "en del betydning « og $0 \%(\bmod 8,3 \%$ i 2002$)$ at den vil have "altafgørende betydning« for, om der blev givet en god karakter på det skriftlige arbejde. Igen kan det være den ændrede situation på arbejdsmarkedet, der er årsagen til, at de studerende nu generelt har en højere ambition om at afslutte deres uddannelse, end de har om at få en høj karakter på opgaverne.

\begin{tabular}{|l|l|l|l|l|l|l|l|l|}
\hline \multirow{2}{*}{ De studerende har en forventning om en vejleder, der } & \multicolumn{2}{l}{ Temaopgaver } & \multicolumn{2}{l|}{ Projekter } & \multicolumn{2}{l|}{ Specialer } & \multicolumn{2}{l|}{ I alt } \\
\cline { 2 - 11 } & 2002 & 2006 & 2002 & 2006 & 2002 & 2006 & 2002 & $\mathbf{2 0 0 6}$ \\
\hline er forberedt til møderne & 2,0 & $\mathrm{I}, 7$ & 2,0 & $\mathrm{I}, 5$ & $\mathrm{I}, 8$ & 2,0 & $\mathrm{I}, 9$ & $\mathrm{I}, \mathbf{7}$ \\
\hline overholder de aftaler, der er indgået & $\mathrm{I}, 9$ & 2,0 & $\mathrm{I}, 9$ & $\mathrm{I}, 5$ & 3,2 & $\mathrm{I}, 8$ & 2,3 & $\mathbf{2 , 3}$ \\
\hline har en specifik, faglig indsigt i emnet & 3,4 & 3,0 & 3,5 & 3,4 & 2,7 & 2,9 & 3,2 & $\mathbf{3 , 1}$ \\
\hline har detaljeret kendskab til studieordningen & 3,0 & 3,0 & 2,2 & 3,1 & 3,4 & 3,5 & 2,9 & $\mathbf{3 , 2}$ \\
\hline retter den studerendes tekst & 4,6 & 4,7 & 5,0 & 5,8 & 4,8 & 4,4 & 4,8 & $\mathbf{5 , 0}$ \\
\hline er enig med den studerende & 5,8 & 5,8 & 5,8 & 5,8 & 5,4 & 5,6 & 5,6 & $\mathbf{5 , 6}$ \\
\hline
\end{tabular}

Figur 4. Forventninger til vejlederen. De studerende har i besvarelserne prioriteret de enkelte elementer med værdierne I til 6, hvor I angiver højeste prioritet. Resultaterne i dette skema er fremkommet ved, at den samlede værdi af prioriteringerne for den enkelte gruppe er divideret med

terniveau. Vejledningen drejer sig primært om specialets problemformulering, litteratursøgning, specifikke faglige problemer, arbejdsprocessen og henvisninger til relevante fagmiljøer. Vejlederen er forberedt til møderne, overholder de aftaler, der indgås, og læser gerne halvdelen af den færdige tekst igennem, inden specialet afleveres.

Desuden bør det tilføjes, at alle studerende har lige adgang til vejledning, at vejledningen fordeles ligeligt mellem underviserne, og at de studerende tilskyndes til ikke at anvende samme vejleder på alle overbygningsopgaver.

Det skal i de kommende år blive interessant at se, om det administrative aspekt $\mathrm{i}$ disse rammer letter vejledningspraksis - for studerende og for undervisere. Med hensyn til det faglige aspekt er der allerede nu ingen tvivl om, at vejledningen indtager sin ligeværdige andel af uddannelsens læringsproces, og dermed også er tydeliggjort som en del af undervisernes arbejds- og kompetenceområder. 